
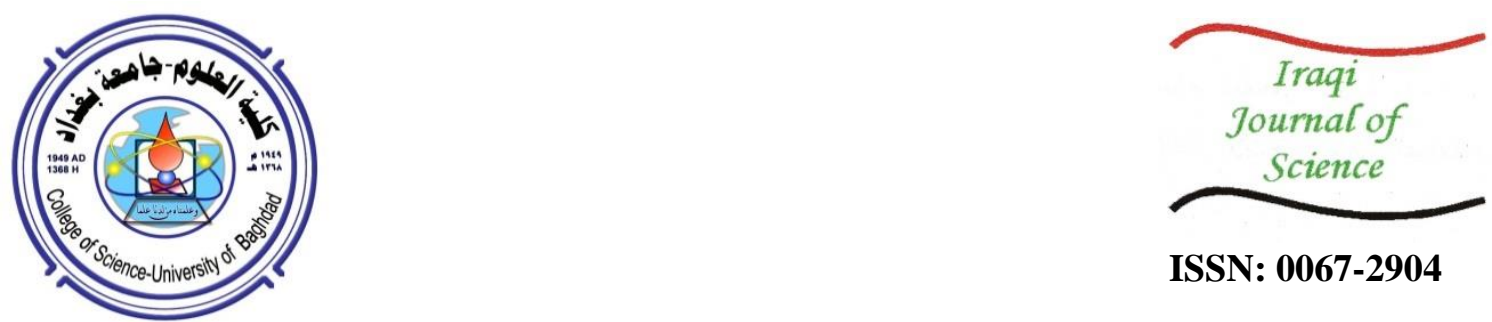

ISSN: 0067-2904

\title{
In Vitro Effects of Different Combinations of Phytohormones on Callus Induction from Different Explants of Cabbage Brassica Oleracea Var. Capitata L. Seedlings
}

\author{
Alaa. M. Hasan ${ }^{* 1}$, Ekhlas. A.J. ElKaaby ${ }^{2}$, Rakad. M.Kh. AL-Jumaily ${ }^{1}$ \\ ${ }^{I}$ Department of Biology, College of Sciences, University of Baghdad, Baghdad, Iraq \\ ${ }^{2}$ Department of Genetic Engineering, College of Agricultural Engineering Sciences, University of Baghdad \\ Baghdad, Iraq
}

Received: $11 / 1 / 2020$

Accepted: 5/4/2021

\begin{abstract}
The leading purpose of this work is the development of efficient culture conditions to induce calli from cabbage (Brassica oleracea var. capitata L.) under in vitro conditions. The mature seeds were surface sterilized with combinations of different concentrations of ethanol and $\mathrm{NaOCl}$ in different time durations and were germinated on MS basal medium. The results revealed that the best sterilization method of cabbage seeds was by using $70 \%$ ethanol for one minute, followed by 15 $\min$ in $2 \%(\mathrm{NaOCl})$. Seedlings were used as donor sources for hypocotyls, cotyledon leaves, true leaves, and shoot tip explants. These explants were cultured on different combinations of cytokinins (TDZ, BAP, Ad) and auxins (IAA, NAA, 2, 4-D) then implanted in Murashige and Skoog (MS) media. 4 weeks after culturing, a significant difference was found among the explants in response to plant hormones. The maximum percentage of callus induction (100\%) was using the combinations of $1 \mathrm{BAP}+12$, 4-D, $1 \mathrm{BAP}+1 \mathrm{NAA}$, and $1 \mathrm{BAP}+22,4-\mathrm{D} \mathrm{mg}$. $\mathrm{l}^{-1}$. In addition, explants responses varied and the hypocotyls showed a superior result $(85.71 \%)$ as compared to other explants. For callus fresh weight, the combination of $0.22 \mathrm{TDZ}+$ $79.9 \mathrm{Ad} \mathrm{mg.} \mathrm{l}^{-1}$ had a significant effect, causing the highest fresh weight $(0.2745 \mathrm{~g})$, while control treatment gave the lowest mean of $0.0066 \mathrm{~g}$. Data showed that cotyledon explants were significantly superior in giving highest callus fresh weight with the mean of $0.1723 \mathrm{~g}$. On the other hand, hypocotyl explants gave the lowest mean, reaching $0.1542 \mathrm{~g}$.
\end{abstract}

Keywords: Brassica oleracea var. capitata L., Fresh weight, IAA, NAA, 2, 4-D, hypocotyls, cotyledon leaves, shoot tips
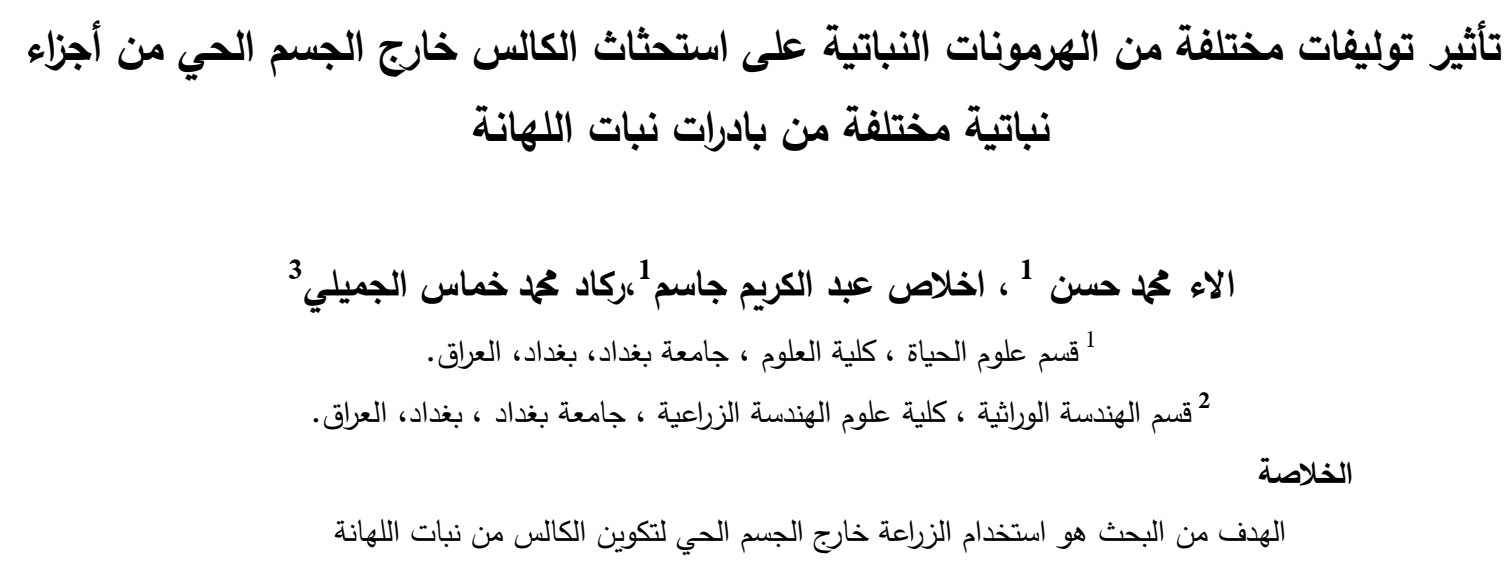

*Email: alaayhasan@gmail.com 


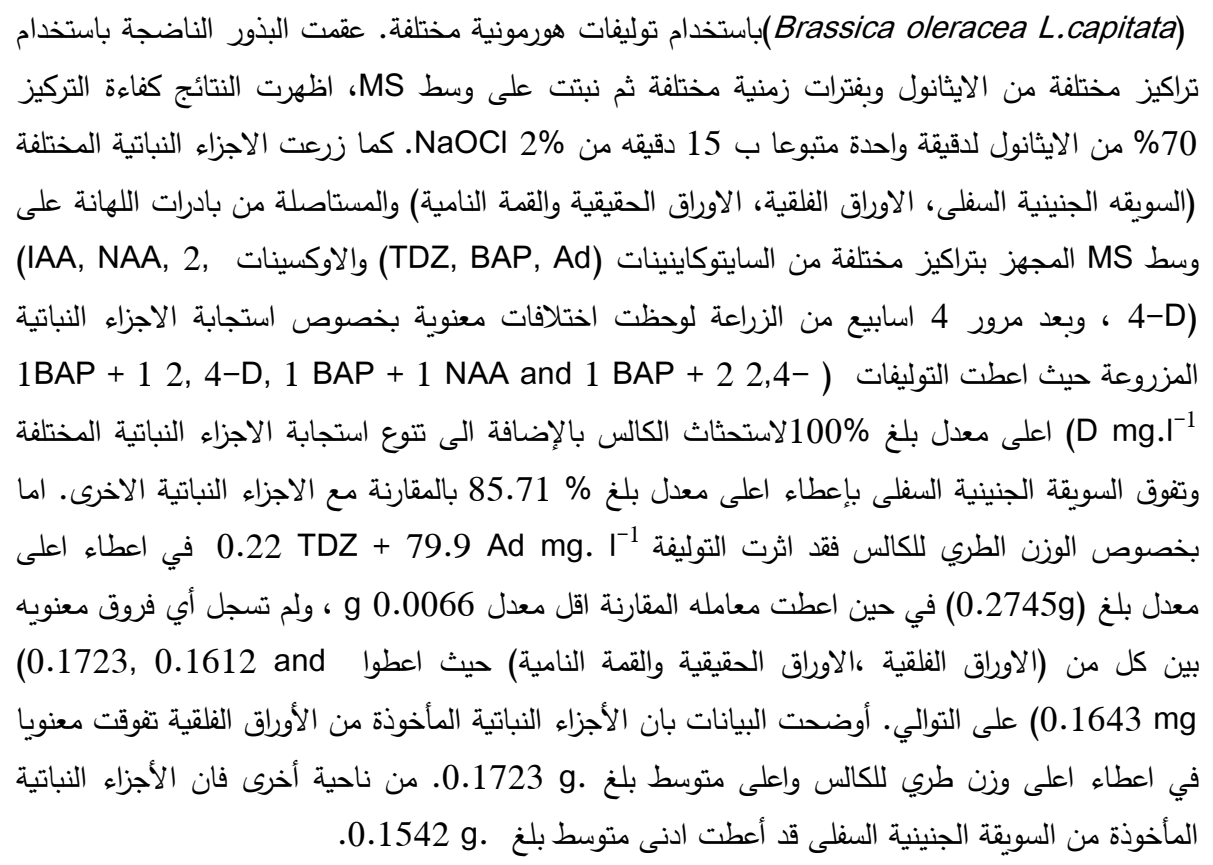

\section{Introduction}

Cabbage (Brassica oleracea var. capitata L.) belongs to the family of Brassicaceae. It is one of the most common vegetables grown worldwide and often referred to as green cabbage to distinguish it from red cabbage, which has the same scientific name [1]. Cruciferae family is one of the largest families in the plant kingdom, which is famous as a source of medicinal plants as well as its nutritional properties. It includes 338 genera and 3350 species that are distributed worldwide [2].

Methanolic and aqueous crud extracts of $B$. oleracea seeds showed an inhibitory effect on both Gram-positive and Gram-negative bacteria [3]. It was also concluded that Brassica oleracea var. capitata (red cabbage) is considered as a novel inhibitor for uricase isolated from Pseudomonas aeruginosa, possibly used to treat gout disease in the future [4].

Cabbage, B. oleracea var. capitata $L$., is one of the most common vegetables in the world. Because it contains high levels of flavonoids and anthocyanins, cabbage has been long used as a herbal medicine. The antioxidant and anti-inflammatory properties of cabbage were also recently reported [5].

The parts of Brassica plants that are used as food and medicine include root, shoot, stem, leaves, leaf buds, flower buds, florets, inflorescence, seeds, seed oil, and callus. Furthermore, these plants are very rich in a variety of nutrients, such as carbohydrates, lipids, protein, vitamins, and minerals, along with phytochemical components of medicinal value [6].

In recent years, major efforts in Brassicaceae research have focused on using tissue culture technology for crop improvement. Direct in vitro plant regeneration is a very important step for mass production of genetically identical or uniform plants, due to somatic propagation, which may be used later as vegetative clones. In vitro techniques have also been applied to Brassicas from different points of view, resulting in organogenesis, somatic embryogenesis, and regeneration [7-9]. Considerable research has been carried out in the regeneration of the Brassicaceae crop plants.

The conditions of all experiments are specific for the variety under investigation. Therefore, the main objective of the current study is to test the ability of cabbage explants for callus induction under the influence of different growth regulators using a native cultivar of Brassica oleracea var. capitata $L$. 


\section{Materials and Methods}

This study was performance at the laboratory of tissue culture of the Department of Genetic Engineering, Food and Biotechnology Center, Ministry of Sciences and Technology, Baghdad, Iraq, during the years 2019-2020. Mature seeds of green cabbage local cultivar were purchased from a local market and used in this study.

Seed sterilization and germination

Seeds of green cabbage were surface sterilized with ethanol and sodium hypochlorite $(\mathrm{NaOCl})$, successively at different durations at different periods and concentrations, as shown in Table 1. Ten seeds were cultured in each glass jar, while the treatment was replicated five times. All steps of sterilization were carried out under aseptic conditions in a Laminar Air Flow Hood. Seeds were cultured on Murashige and Skoog, 1962, (MS) salts medium solidified with $7 \mathrm{~g} .1^{-1}$ of agar (Figure1) and incubated at room temperature $\left(25 \pm 2{ }^{\circ} \mathrm{C}\right), 16 \mathrm{~h}$ light of 1000 Lux intensity, and $8 \mathrm{~h}$ darkness [10]. 10 days later, the results of contamination and seed germination were recorded. The seedlings were used as a donor source for explants.

\begin{tabular}{c|ccc}
\hline Treatment & Time (min) & Concentrations & References \\
\hline D.D Water & ---- & ---- & ----- \\
Ethanol $+\mathrm{NaOCl}$ & 5 each & $50 \%(\mathrm{v} / \mathrm{v})$ each & {$[11]$} \\
Ethanol + $\mathrm{NaOCl}$ & $1+15$ & $70 \%+2 \%$ & {$[12]$} \\
Ethanol + $\mathrm{NaOCl}$ & $1+20$ & $70 \%+20 \%(8 \%)$ & {$[13]$} \\
& & $70 \%+20 \%(1.05 \%)$ & {$[14]$} \\
Ethanol + $\mathrm{NaOCl}$ & $1+10$ & & \\
\hline
\end{tabular}

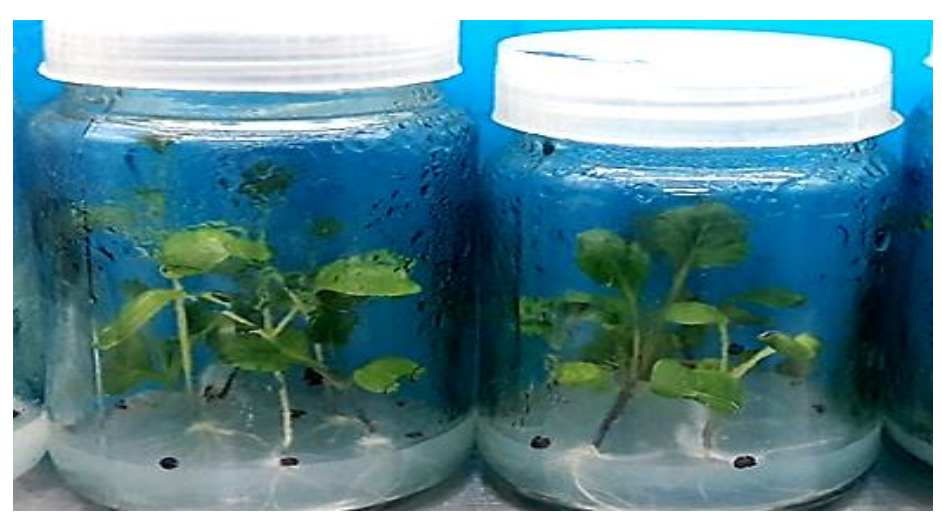

Figure 1-Germination of cabbage seeds in culture media

\section{Callus induction medium}

For callus induction, cotyledon leaves, true leaves, hypocotyls, and shoot tips were separated and cultured on six types of media, according to previous literature reviewed in $\mathrm{T}$ Table 2, (Figure 2). The culture was incubated at the same condition of the germinated seeds mentioned previously, while the results were recorded after 4 weeks. 
Table 2- Media combinations used in the present study for the culturing and initiation of callus along with their citing references. $\mathrm{TDZ}=($ Thidiazuron $), \mathrm{BAP}=($ Benzyl Amino Purine $), A d=($ Adenine $), \mathrm{IAA}=($ Indole Acetic Acid $), \mathrm{NAA}=($ Naphthalene Acetic Acid $)$, 2,4-D $=($ Dichlorophenoxyacetic acid $)$.

\begin{tabular}{|c|c|c|c|}
\hline Media combinations & References & Type of plant & Type of explant \\
\hline $\begin{array}{c}0.5 \mathrm{mg} . \mathrm{L}^{-1} \mathrm{NAA}+0.25 \mathrm{mg} . \mathrm{L}^{-1} \mathrm{TDZ}+3.0 \\
\mathrm{mg} \cdot \mathrm{L}^{-1} \mathrm{BA}\end{array}$ & [15] & Cauliflower & $\begin{array}{l}\text { Hypocotyls, } \\
\text { cotyledon }\end{array}$ \\
\hline $1 \mathrm{mg} \cdot \mathrm{L}^{-1} \mathrm{BAP}+1 \mathrm{mg} \cdot \mathrm{L}^{-1} \mathrm{NAA}$ & [16] & Cabbage & $\begin{array}{l}\text { stems, leaves, } \\
\text { roots and petioles }\end{array}$ \\
\hline $\begin{array}{c}\mathrm{MS}+0.22 \mathrm{mg} . \mathrm{L}^{-1} \mathrm{TDZ}+79.9 \mathrm{mg} . \mathrm{L}^{-1} \\
\text { Adenine }\end{array}$ & [17] & Cabbage & $\begin{array}{c}\text { Hypocotyls, } \\
\text { cotyledon }\end{array}$ \\
\hline $1 \mathrm{mg} \cdot \mathrm{L}^{-1} \mathrm{BAP}+2 \mathrm{mg} \cdot \mathrm{L}^{-1} 2,4-\mathrm{D}$ & $\begin{array}{l}\text { Researcher } \\
\text { combination }\end{array}$ & Cabbage & $\begin{array}{l}\text { stems, leaves, } \\
\text { cotyledons, } \\
\text { Hypocotyls, }\end{array}$ \\
\hline $1 \mathrm{mg} . \mathrm{L}^{-1} \mathrm{BAP}+1 \mathrm{mg} \cdot \mathrm{L}^{-1} 2,4-\mathrm{D}$ & $\begin{array}{l}\text { Researcher } \\
\text { combination }\end{array}$ & Cabbage & $\begin{array}{l}\text { Hypocotyls, } \\
\text { cotyledon }\end{array}$ \\
\hline $0.5 \mathrm{mg} . \mathrm{L}^{-1} \mathrm{BAP}+2.0 \mathrm{mg} \cdot \mathrm{L}^{-1} \quad 2,4-\mathrm{D}$ & [18] & $\begin{array}{l}\text { Cabbage and } \\
\text { Cauliflower }\end{array}$ & hypocotyls \\
\hline
\end{tabular}

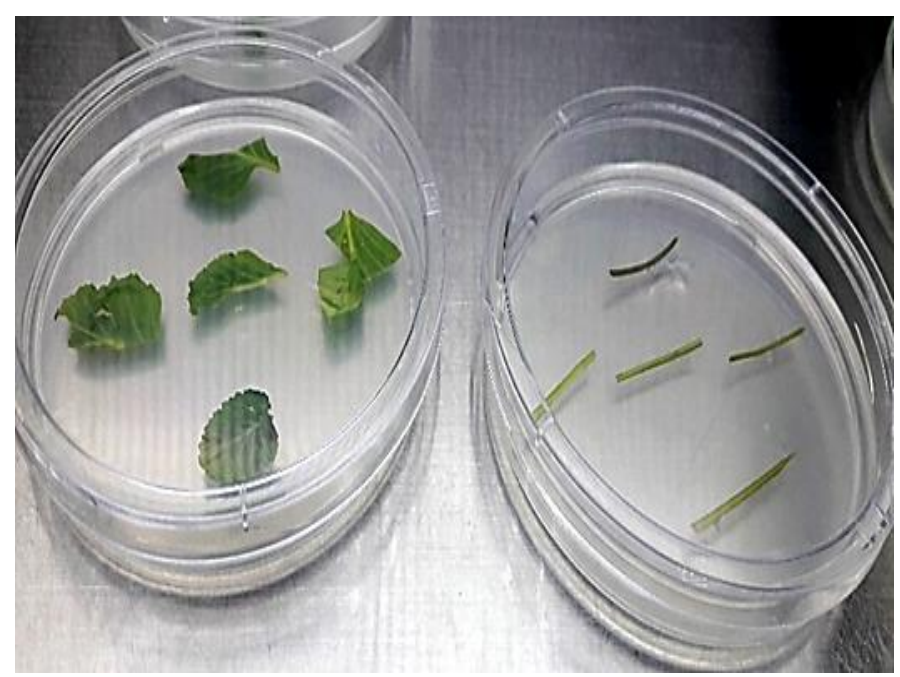

Figure 2-Leaves and hypocotyl explants separated from cabbage seedlings and cultured on callus induction media

\section{Statistical analysis}

All the tests were performed by using the Completely Randomized Design (C.R.D) with 5 replicates for each treatment. Collected data was analyzed via Gen Stat program [19] and the means were compared via DUNCAN multiple range test.

\section{Results}

Seeds sterilization and germination

According to the outcomes of surface sterilization and seed germination in Table 3, the highest contamination percentage $(100 \%)$ was found at control (D.D water) treatment, while lower $(0 \%)$ contamination percentage was found at $70 \%$ ethanol $1 \mathrm{~min}+2 \% \mathrm{NaOCl} 15 \mathrm{~min}$. For the germination, the highest germination $(100 \%)$ was observed when seeds were treated with $70 \%$ ethanol $1 \mathrm{~min}+2 \% \mathrm{NaOCl} 15 \mathrm{~min}$, with no contamination observed (Figure 1), while a germination ration of $10 \%$ was recorded when the seeds were treated with D.D water. 
Table 3- Effects of different ethanol and sodium hypochlorite concentrations on seeds contamination (\%) and germination (\%) of cabbage.

\begin{tabular}{|c|c|c|}
\hline Treatments & Contamination (\%) & Germination (\%) \\
\hline D.D Water & $100 \mathrm{a}$ & $10 \mathrm{c}$ \\
\hline $\begin{array}{l}50 \% \text { Ethanol } 5 \mathrm{~min}+50 \% \mathrm{NaOCl} \\
5 \mathrm{~min}\end{array}$ & $32 \mathrm{~b}$ & $64 \mathrm{~b}$ \\
\hline $\begin{array}{c}70 \% \text { Ethanol } 1 \mathrm{~min}+2 \% \mathrm{NaOCl} \\
15 \mathrm{~min}\end{array}$ & $0 \mathrm{~d}$ & $100 \mathrm{a}$ \\
\hline $\begin{array}{l}70 \% \text { Ethanol } 1 \mathrm{~min}+20 \% \mathrm{NaOCl} \\
20 \mathrm{~min}\end{array}$ & $8 \mathrm{~cd}$ & $100 \mathrm{a}$ \\
\hline $\begin{array}{l}70 \% \text { Ethanol } 1 \mathrm{~min}+20 \% \mathrm{NaOCl} \\
10 \mathrm{~min}\end{array}$ & $20 \mathrm{bc}$ & $100 \mathrm{a}$ \\
\hline
\end{tabular}

*Each number represents average of five replicates.

** The same letter represents no significant differences among the numbers within the same column.

Effects of explant and growth regulators on callus induction (\%)

The results in Table 4 reveal various responses for callus percentage, where most of hormonal combinations exhibited positive effects. However, no significant differences were found among $1 \mathrm{BAP}+12$, 4-D, $1 \mathrm{BAP}+1 \mathrm{NAA}$ and $1 \mathrm{BAP}+22,4-\mathrm{D}$ mg. $1^{-1}$ treatments, which gave $100 \%$ for each, and control treatment (MS free hormones) which presented the weakest response (4\%), as shown in Table 4. For explants response, data in the same table show that hypocotyl explants were significantly superior, giving the highest callus percentage $(85.71 \%)$, while leaves gave the weakest response of $62.86 \%$ (Figure 3).

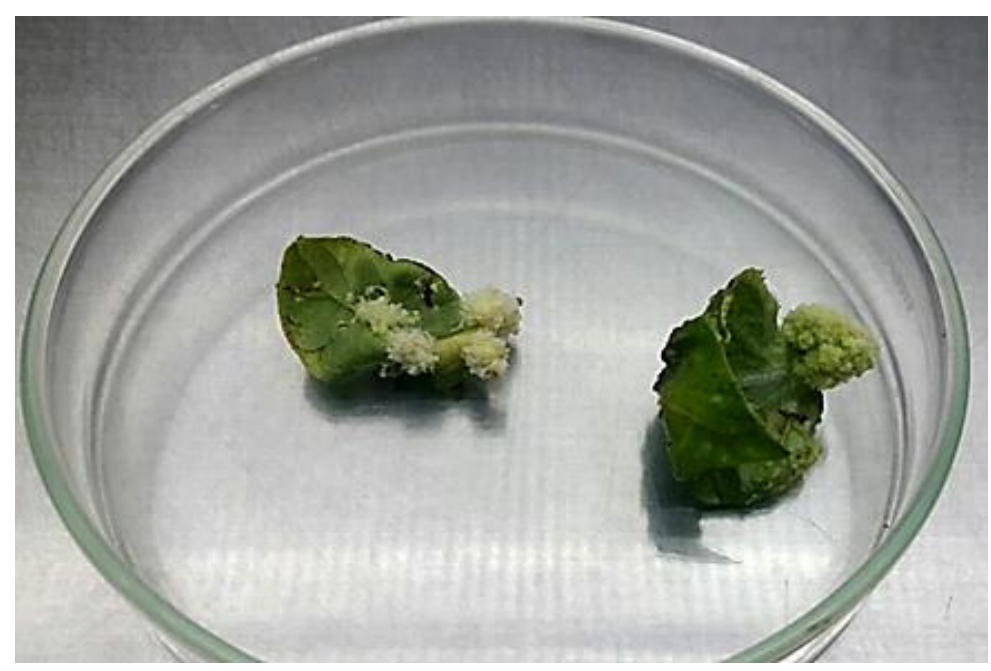

Figure 3-Callus induction from leaves explants were cultured in media supported with $1 \mathrm{mg}$.

$$
\mathrm{L}^{-1} \mathrm{BAP}+2 \mathrm{mg} \cdot \mathrm{L}^{-1} 2,4-\mathrm{D}
$$

Data revealed that the combinations of $1 \mathrm{BAP}+12$, 4-D, $1 \mathrm{BAP}+1 \mathrm{NAA}$, and $1 \mathrm{BAP}+2$ 2, 4-D mg. $~^{-1}$ gave $100 \%$ callus induction from cotyledons, hypocotyls, leaves, and shoot tips. There were no significant differences among other combinations $(0.22 \mathrm{TDZ}+79.9$ Ad, 0.5 $\mathrm{NAA}+0.25 \mathrm{TDZ}+3 \mathrm{BA} \mathrm{mg} .1^{-1}$ for cotyledons and hypocotyls and $0.5 \mathrm{BAP}+22$, 4-D mg. $1^{-}$ ${ }^{1}$ for hypocotyls) which gave induction values of 100 and $92 \%$, respectively (Figure 4). 


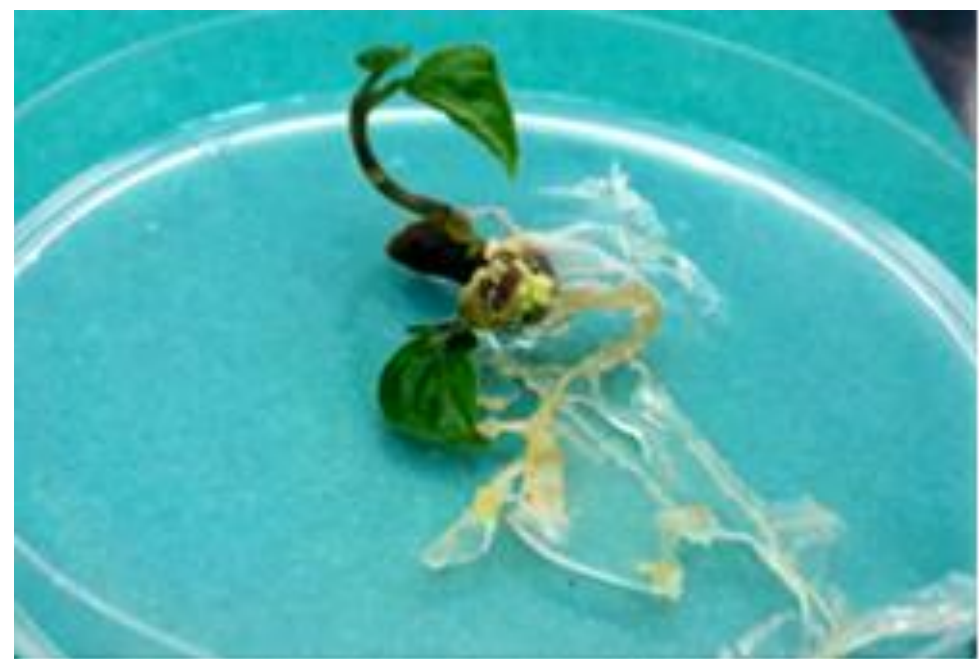

Figure 4-Shoot, roots, and callus initiated from hypocotyls explants.

Table 4- Effects of different hormonal combinations on \% callus induction from different Type of explants

\begin{tabular}{c|ccccc}
\multicolumn{1}{c}{$\begin{array}{c}\text { Treatments } \\
\text { mg. } \text { L }^{-1}\end{array}$} & Cotyledons & Hypocotyls & Leaves & Shoot tips & Mean \\
\hline Control & $0 \mathrm{f}$ & $8 \mathrm{f}$ & $0 \mathrm{f}$ & $8 \mathrm{f}$ & $4.00 \mathrm{~d}$ \\
$0.22 \mathrm{TDZ}+79.9 \mathrm{Ad}$ & $100 \mathrm{a}$ & $100 \mathrm{a}$ & $44 \mathrm{e}$ & $64 \mathrm{~d}$ & $77.00 \mathrm{bc}$ \\
$0.5 \mathrm{BAP}+22,4-\mathrm{D}$ & $64 \mathrm{~d}$ & $92 \mathrm{ab}$ & $52 \mathrm{e}$ & $80 \mathrm{c}$ & $72.00 \mathrm{c}$ \\
$0.5 \mathrm{NAA+}+0.25 \mathrm{TDZ}+3$ & $100 \mathrm{a}$ & $100 \mathrm{a}$ & $44 \mathrm{e}$ & $84 \mathrm{bc}$ & $82.00 \mathrm{~b}$ \\
$\begin{array}{c}\text { BA } \\
1 \mathrm{BAP}+12,4-\mathrm{D}\end{array}$ & $100 \mathrm{a}$ & $100 \mathrm{a}$ & $100 \mathrm{a}$ & $100 \mathrm{a}$ & $100 \mathrm{a}$ \\
$1 \mathrm{BAP}+1 \mathrm{NAA}$ & $100 \mathrm{a}$ & $100 \mathrm{a}$ & $100 \mathrm{a}$ & $100 \mathrm{a}$ & $100 \mathrm{a}$ \\
$1 \mathrm{BAP}+22,4-\mathrm{D}$ & $100 \mathrm{a}$ & $100 \mathrm{a}$ & $100 \mathrm{a}$ & $100 \mathrm{a}$ & $100 \mathrm{a}$ \\
& $80.57 \mathrm{~b}$ & $85.71 \mathrm{a}$ & $62.86 \mathrm{~d}$ & $76.57 \mathrm{c}$ & \\
\hline
\end{tabular}

* Means followed by the same letters are not significantly different from each other within the single variant or the two interactions, at a significance of 5\% level according to Duncan's multiple range test.

Effects of Growth Regulators on calli fresh weight

The results in Table 5 reveal various responses for callus fresh weight from different explants in different hormonal combinations, which ranged from $0.3074 \mathrm{~g}$ using $0.22 \mathrm{TDZ}+79.9 \mathrm{Ad}$ to $0.0528 \mathrm{~g}$ using $1 \mathrm{BAP}+1 \mathrm{NAA}$. No significant differences were found between $1 \mathrm{BAP}+1$ 2, 4-D and 1 BAP + 1 NAA, which gave similar results of $0.1366 \mathrm{~g}$ and $0.1391 \mathrm{~g}$, respectively. The best combination was $0.22 \mathrm{TDZ}+79.9$ Ad with a mean weight reaching $0.2745 \mathrm{~g}$. Data showed that cotyledon explants were significantly superior to give highest callus fresh weight, which reached $0.2786 \mathrm{~g}$, with the highest mean reached $0.1723 \mathrm{~g}$. On the other hand, hypocotyl explants gave the lowest mean, reaching $0.1542 \mathrm{~g}$. 
Table 5- Effects of different hormonal combinations on callus fresh weight (g) of cabbage explant's

\begin{tabular}{c|ccccc}
\hline \multicolumn{1}{c}{$\begin{array}{c}\text { Treatment } \\
\text { mg. } \text { L }^{-1}\end{array}$} & Cotyledons & Hypocotyls & Leaves & Shoot tips & Mean \\
\hline Control & $0.0000 \mathrm{~m}$ & $0.0082 \mathrm{~m}$ & $0.0000 \mathrm{~m}$ & $0.0184 \mathrm{~m}$ & $0.0066 \mathrm{f}$ \\
$0.22 \mathrm{TDZ}+79.9 \mathrm{Ad}$ & $0.2970 \mathrm{a}$ & $0.1998 \mathrm{ef}$ & $0.2938 \mathrm{a}$ & $0.3074 \mathrm{a}$ & $0.2745 \mathrm{a}$ \\
$0.5 \mathrm{BAP}+22,4-\mathrm{D}$ & $0.2380 \mathrm{~cd}$ & $0.1370 \mathrm{iik}$ & $0.1756 \mathrm{fgh}$ & $0.2140 \mathrm{de}$ & $0.1912 \mathrm{c}$ \\
$0.5 \mathrm{NAA}+0.25 \mathrm{TDZ}+3$ & $0.1540 \mathrm{hii}$ & $0.1616 \mathrm{fgii}$ & $0.1304 \mathrm{ik}$ & $0.1672 \mathrm{fghi}$ & $0.1533 \mathrm{~d}$ \\
BA & $0.1854 \mathrm{efgh}$ & $0.1112 \mathrm{k}$ & $0.1128 \mathrm{k}$ & $0.1372 \mathrm{iik}$ & $0.1366 \mathrm{e}$ \\
1 BAP + 1 2, 4-D & $0.0528 \mathrm{l}$ & $0.2126 \mathrm{de}$ & $0.1766 \mathrm{fgh}$ & $0.114 \mathrm{k}$ & $0.1391 \mathrm{de}$ \\
1 BAP + 1 NAA & $0.2786 \mathrm{ab}$ & $0.2490 \mathrm{bc}$ & $0.2392 \mathrm{~cd}$ & $0.1916 \mathrm{efg}$ & $0.2396 \mathrm{~b}$ \\
1 BAP + 2 2, 4-D & $0.1723 \mathrm{a}$ & & $0.1612 \mathrm{ab}$ & $0.1643 \mathrm{ab}$ & \\
\hline Mean & & $0.1542 \mathrm{~b}$ & $0.1612 \mathrm{ab}$ & \\
\hline
\end{tabular}

* Means followed by the same letters are not significantly different from each other within the single variant or the two interactions, at a significance of 5\% level according to Duncan's multiple range test.

\section{Discussion}

Our results showed that the best treatment for both contamination (\%) and germination (\%) of white cabbage seeds was $70 \%$ ethanol $1 \mathrm{~min}+2 \% \mathrm{NaOCl} 15 \mathrm{~min}$, as illustrated in (Table 3 ). The successful establishment of a contamination-free culture is a critical stage in obtaining an aseptic explant [20-21]. Sodium hypochlorite is a strong sterilizing agent that is used widely in in vitro applications. However, it was found that the sterilization of sunflower seeds with 5\% marketable bleach and dry heating gave the best results to overcome the difficulties of internal bacterial infection [22]. Other researchers used antibiotics [23] or fungicides [2425] when the repetitive surface sterilization technique become insufficient. In this study, $\mathrm{NaOCl}$ showed a positive role as an eliminator of microorganisms, due to the hypochlorous acid activity, which is formed when the $\mathrm{NaOCl}$ reacts with $\mathrm{H}_{2} \mathrm{O}$ and releases $\mathrm{Cl}$ [26]. This result agrees with those reported by other groups [27-29].

Many researches indicated the important role of synergistic effects of auxins and cytokinins in callus induction media [30- 33], also in addition to the usage of definite concentrations to stimulate either callogenesis or organogenesis of different tissue explants for different plants. Callus initiation depends greatly on the balance of auxins and cytokinins in the cells, which plays a vital role in cell division. Cytokinins are necessary for the growth of plants in tissue culture, as well as the cell divisions that yield undifferentiated callus [34].

Goodwin [35] and Taiz and Zeiger [36] stated that the ideal auxin concentration leads to an increase of rRNA transcription, multiplication, and enzyme activity which will increase the growth of callus. Furthermore, TDZ has shown both auxin and cytokinin-like effects, although, chemically, it is totally different from commonly used auxins and cytokinins [37].

In most Brassica species, regeneration depends on the age of explants [38 - 39], with younger explants resulting in better responses [40]. In addition, de novo organogenesis is depending on somatic cell totipotency, which enables plants to regenerate organs from wounded parts or excised explants in vitro [41]. This process is commonly divided into several distinct events: callus induction, induced partition of cell identity within the callus, radial patterning within shoot progenitors, and shoot apical meristem morphogenesis [42]. Explants from 3- or 4days old seedlings gave optimum regeneration rates in different Brassica spp.; nevertheless, these explants are too small and, therefore, they are difficult to manipulate [43-44, 38]. This is the reason why most researchers used explants excised from 5- to 7- or even 10- days old seedlings [45-47]. 
In this study, when leaf and hypocotyl explants derived from young seedlings (age 7- 10- dold) were cultured on callus induction media, they showed better and more varied response to callus (Figure 3), along with indirect organogenesis (Figure 4). The best media combinations for callus induction were $1 \mathrm{BAP}+12$, 4-D, $1 \mathrm{BAP}+1 \mathrm{NAA}$, and $1 \mathrm{BAP}+2$ 2, 4-D mg. ${ }^{-1}$, which gave $100 \%$ callus induction from cotyledons, hypocotyls, leaves and shoots (Table 4). However, a previous study [18] stated that higher concentrations of cytokinins were important for plantlet regeneration, since higher concentrations of auxin caused only an increase in callus size with no or very little regeneration observed. Our findings agreed with this statement. Some scientists gained rapid shoot multiplication of the transgenic Brassica oleracea at MS enhanced with different concentrations of BAP and NAA. Thus, it can be concluded that the age of explants is important for their capability to regenerate.

\section{Conclusions}

Based on the results obtained from this study, it is concluded that all explants of cabbage showed a variable response to several hormonal combinations, despite the superiority of hypocotyl and cotyledon leaves explants for callus formation in media containing TDZ, Ad, or BA.

On the other side, a good response was observed indirectly in shoot proliferation in the same media (although all media combinations were for callus initiation) or directly in organogenesis (development of plant organs from callus tissue) in media free hormones. These observations need further studies for soma clonal variations of those plants that were regenerated from callus in this study, along with the need for further screening of abiotic stresses, such as drought or salt tolerance.

\section{Acknowledgment}

I would like to thank the staff of the tissue culture laboratory of the Genetic Engineering Department, Food and Biotechnology Centre, Ministry of Sciences and Technology, for their help and provision of equipment needed for experiments.

\section{References}

[1] S. Rokayya, CJ. Li, Y. Zhao, Y. Li, and CH. Sun, "Cabbage (Brassica oleracea L. Var. capitata) phytochemicals with antioxidant and anti-inflammatory potential," Asian Pac J Cancer Prev, vol. 14, pp. 6657- 62, 2014.

[2] S. S. Emam and H. I. Abd El-Moaty, "Glucosinolates, Phenolic acids and Anthraquinones of Isatis microcarpa Boiss and Pseuderucaria clavate (Boiss\&Reut.) family: Cruciferae, " Journal of Applied Sciences Research, vol. 5, no. 12, pp. 2315-2322, 2009.

[3] Y. Lee, S. Kim, B. Yang, C. Lim, J. H. Kim, H. Kim, and S. Cho, "Anti-inflammatory Effects of Brassica oleracea Var. capitata L. (Cabbage) Methanol Extract in Mice with Contact Dermatitis," Pharmacognosy magazine, vol. 14, no. 54, pp. 174-179. 2018.

[4] H. Nawaz, A. S. Muhammad, and M. Saima, Phytochemical Composition and Antioxidant Potential of Brassica, Brassica Germplasm - Characterization, Breeding and Utilization, 2018, Available: https://www.intechopen.com/books/brassica-germplasmcharacterization-breeding-and-utilization/phytochemical-composition-and-antioxidantpotential-of-brassica.

[5] M. R. Majid and H. A. Farhan, "Extracts on some seeds Brassica oleracea the effect of pathogenic bacteria," Iraqi Journal of Science, vol. 51, no. 1, 2010.

[6] WL. Koh and C.S. Loh, "Direct somatic embryogenesis, plant regeneration and In vitro flowering in rapid-cycling Brassica napus," Plant Cell Rep, vol. 19, pp. 1177-1183. 2000.

[7] MR. Khan, H. Rashid and A. Quraishi, "High frequency shoot regeneration from hypocotyl of Canola (Brassica napus L.) cv. Dunkled," Plant Tissue Cult, vol. 12, no. 2, pp. 131-138. 2002a. 
[8] MR. Khan, H. Rashid and A. Quraishi, "Effects of various growth regulators on callus formation and regeneration in Brassica napus cv. Oscar, " Pak J Biol Sci, vol. 5, pp. 693695, $2002 b$.

[10] T. Murashige, and F. Skoog, "A Revised Medium for Rapid Growth and Bio Assays with Tobacco Tissue Cultures," Physiol. Pl,vol. 15, pp. 473- 497, 1962.

[11] A. Gerszberg, K. Hnatuszko-Konka, and T. Kowalczyk, "In vitro regeneration of eight cultivars of Brassica oleracea var. capitata," In Vitro Cell.Dev.Biol.Plant, vol. 51, pp. 8087, 2015.

[9]H. Seul-Hye, and M. Byung-Whan, "Efficient Development of Transgenic Cabbage with Jasmonic Acid Carboxyl Methyltransferase (JMT) Gene Based on PMI /Mannose Selection System," Plant Breed. Biotech, vol.3, no.3, pp. 226- 237, 2015.

[10]S. Pavlović, B. Vinterhalter, N. Mitić, S. Adžić, N. Pavlović, M. Zdravković, D. Vinterhalter, "In vitro shoot regeneration from seedling explants in Brassica vegetables: red cabbage, broccoli, savoy cabbage and cauliflower," Arch Biol Sci, vol. 62, pp. 337$345,2010$.

[11]S. A. Ravanfar, A. A. Maheran, A. R. Azmi, And S. Shahida, "In Vitro Adventitious Shoot Regeneration From Cotyledon Explant Of Brassica Oleracea Subsp. Italica And Brassica Oleracea Subsp. Capitata Using Tdz And Naa," Pak. J. Bot, vol. 46, no.1, pp. 329-335, 2014.

[12] Y. Qin, L. H. Gao, S. Pulli, and Y. D. Guo, "Shoot differentiation, regeneration of cauliflower and analysis of somaclonal variation by RAPD," Hereditas vol. 143, pp. 9198, 2006.

[13] N.F.A. Daud, N.A. Hasbullah, N.A. Azis, F.M. Rasad, M.A.M. Amin and M.M. Lassim, "In vitro Regeneration of Brassica Oleraceae L. Var Capitata through Stems, Roots, Leaves and Petioles Culture," in proceeding of the International Conference on Agricultural, Ecological and Medical Sciences, Phuket (Thailand), 2015.

[14] G. Gambhir, P. Kumar and D.K. Srivasta, "High frequency regeneration of plants from cotyledon and hypocotyl cultures in Brassica oleracea cv. Pride of India," Biotechnology Reports, vol. 15, pp.107-113, 2017.

[15]Z. Qamar, IA. Nasir, GZ. Jahangir, and T. Husnain, "In-vitro Production of Cabbage and Cauliflower," Adv. life sci, vol. 1, no. 2, pp. 112-118, 2014.

[16]A. Glaser, and C. Biggs, "An Introduction to Statistical Methods in GenStat," 2010.

[17] M.S. Al-Mohammed, E.A.J. El-Kaaby, J.A. Al-Anny, and A.J. Musa, "Effect of Salinity Stress and Mutagenic Sodium Azide on Callus Induction and Plant Regeneration of Borage," Journal of Life Sciences, Vol. 8, no. 8, pp. 660- 667, 2014.

[18]E.A.J. El Kaaby, S. A. Al-Ajeel, and Z. N. Al Hattab, "Effect of Plant Hormones on Callus Induction from Fruit and Seedling Explants of Chilli Pepper (Capsicum annuum L.)," Journal of Life Sciences, vol. 9, pp. 18- 26, 2015.

[19]K. Taški- Ajduković, and D.M. Vasić, "Different Sterilization Methods For Overcoming Internal Bacterial Infection In Sunflower Seeds," Zbornik Matice srpske za prirodne nauke / Proc. Nat. Sci, Matica Srpska Novi Sad, no. 109, pp. 59 - 64. 2005.

[20] J.B. Jerico, F. Adriana, B-Uc. Eduardo, G-Uc. Eunice, and L. R. Manuel, "Improvement of In vitro Proliferation and Elongation of Habanero Pepper Shoots (Capsicum chinense Jacq.) by Temporary Immersion," American Society for Horticultural Science, vol. 45, no. 7, pp. 1093-1098, 2010.

[21]L. B. Danny, "Effects of Light, Surface Sterilization, and Fungicides on the Germination of Black Huckleberry Seeds," Small Fruits Review, vol. 2, no. 2, pp. 73-80, 2003.

[22] K. K. Sharma, U. S. Singh, P. Sharma, A. Kumar, and L. Sharma, "Seed treatments for sustainable agriculture", A review. J. Nat. Appl. Sci, vol. 7, pp. 521-539, 2015. 
[23] V.N. Rodeva, T. P. Irikova and V.J. Todorova, "Another Culture of Pepper (Capsicum annuum L.): Comparative Study on Effect of the Genotype," Biotechnology and Biotechnological Equipment, vol. 18, no. 3, pp. 34-38. 2004.

[24] R. Hasnat, N. A. Abbasi, T. Ahmad and I. A. Hafiz, "Induction and Regeneration of Hypocotyls Derived Calli in Chilli Chilli (Capsicum frutescens L.)," Pak. J. Bot. vol. 39, no. 5, pp. 1787-1795, 2007.

[25]L. K. Gudeva and S. S. Veselinovska, "Some Physiological Characteristics of Pepper (Capsicum annuum L.) Produced In vitro," J. of Biology, vol. 7, no. 1, pp. 1-5, 2011.

[26]Z. M Jaafar, E. A. J, El -Kaaby, R.S. Mouhamad, J. A. AI-Anny, H.K. Hasan and R. A. Mousa, "In vitro effect of plants hormones on seeds germination and callus induction of four Eggplants cultivars (Solanum melongena.L)," International Journal of Multidisciplinary and Current Research, vol. 5, pp. 823- 826, 2017.

[27]D. Xie and Y. Hong, "In-vitro Regeneration of Acacia mangium via Organogenesis," Plant Cell, Tissue and Organ Culture, vol. 66, pp. 167-173, 2001.

[28]H. Meftahizade, M. Lotfi, and H. Moradkhani, "Optimization of Micropropagation and Establishment of Cell Suspension Culture in Melissa officinalis L." African. J. of Biotechnology, vol. 9. no. 28 pp. 4315- 4321, 2010.

[29] A.H.A. Abdelmageed, Q.Z. Faridah, K.N. Suhada, and A.A. Julia, "Callus Induction and Plant Regeneration of Michelia champaca (Magnoliaceae): A Multipurpose Tree," Journal of Medicinal Plant Research, vol. 6, no. 17, pp. 3338- 3344. 2012.

[30] J. Sundarasekar, J.J.J. Anthony, V. Murugaiyah and S. Subramaniam, "Preliminary Responses of 2, 4-D and BAP on Callus Initiation of an Important Medicinal Ornamental Hymenocallis littoralis plants," Journal of Medicinal Plant Research, vol. 6, no. 11, pp. 2088- 2093, 2012.

[31] G. E. Schaller, H. S. Ian and J. K. Joseph, "Cytokinin and the cell cycle, Current Opinion in Plant Biology, vol. 21, pp. 7-15, 2014.

[32] M. Goodwin, 1985. Introduction to Plant Biochemistry.New York: Pergamon Press.

[33]L. Taiz, and E. Zeiger, "Plant Physiology" , ( $3^{\text {ed }}$ edn), Sinauer Associates, Sunderland, MA. Ann Bot vol. 9, no. 6, pp. 750- 751, 2002.

[34]B. Guo, H. A. Bilal, Z. Amir, L. L. Xu and Y. H. Wei," Thidiazuron: A multidimensional plant growth regulator, "African Journal of Biotechnology, vol. 10, no. 45, pp. 8984-9000, 2011.

[35] PL. Bhala and MB. Singh, "Agrobacterium mediated transformation of Brassica napus and Brassica oleracea," Nature Protocols, vol. 3, no. 2, pp. 181-189, 2008.

[36] S. Cogbill, T. Faulcon, G. Jones, M. McDaniel, G. Harmon, R. Blacmon and M. Young, "Adventitious shoot regeneration from cotyledonary explants of rapid-cycling fast plants of Brassica rapa L," Plant Cell Tiss Organ Cult, vol. 101, pp. 127-133, 2010.

[37] J. Ovesna, L. Ptacek and Z. Opatrny, "Factors influencing the regeneration capacity of oilseed rape and cauliflower in transformation experiments," Biol Plant, vol. 35, pp. 107$112,1993$.

[38] H. Motte, D. Vereecke, D. Geelen, S. Werbrouck, "The molecular path to in vitro shoot regeneration," Biotechnol Adv, vol. 32, pp. 107-121, 2014.

[39] J. Duclercq, B. Sangwan-Norreel, M. Catterou, RS. Sangwan, "De novo shoot organogenesis: from art to science," Trends Plant Sci, vol. 16, pp. 597-606, 2011.

[40] V. Cardoza and NC. Stewart, "Brassica biotechnology: progress in cellular and molecular biology In vitro," Cell Dev Biol Plant, vol. 40, pp. 542- 551. 2004.

[41] Y. Zhang and PL. Bhalla, "In vitro shoot regeneration from commercial cultivars of Australian canola (Brassica napus L.)," Aust J Agric Res, vol. 55, pp. 753-756. 2004. 
[42]MK. Munshi, PK. Roy, MH. Kabir G. Ahmed, "In vitro regeneration of cabbage (Brassica oleracea L. var. capitata) through hypocotyl and cotyledon culture," Plant Tissue Cult Biotechnology, vol. 2, pp. 131- 136, 2007.

[43] S. Pavlović, B. Vinterhalter, N. Mitić, S. Adžić, N. Pavlović, M. Zdravković and D. Vinterhalter, "In vitro shoot regeneration from seedling explants in Brassica vegetables: red cabbage, broccoli, savoy cabbage and cauliflower," Arch Biol Sci, vol. 62, pp. 337345, 2010.

[44]A. Rafat, MA. Aziz, AA. Rashid, SNA. Abdullach, H. Kamaladini, MHT. Sirchi and MB. Javadi, "Optimization of Agrobacterium tumefaciens-mediated transformation and shoot regeneration after co-cultivation of cabbage (Brassica oleracea subsp. capitata) cv. KY Cross with AtHSP101 gene," Scientia Horticulture, vol. 124 no. 1, pp. 1- 8, 2010.

[45]P. Lazzeri and J. Dunwell, "In vitro shoot regeneration from seedling root segments of Brassica oleracea and Brassica napus cultivars," Annals of botany, vol. 54, no, 3, pp. 341- 350, 1984.

[46] JH. Kim and J. Botella, "Callus induction and plant regeneration from broccoli (Brassica oleracea var. italica) for transformation," Journal of Plant Biology, vol. 45, no. 3, pp. 177- 181, 2002.

[47] J. Cao, and E. Earle, "Transgene expression in broccoli (Brassica oleracea var. italica) clones propagated In vitro via leaf explants," Plant cell reports, vol. 21, no. 8, 789-796, 2003. 